\section{Norskkunnskaper hos utenlandske leger}

Det medisinske fakultet i Oslo deler fullt ut det syn Michael Bretthauer fremfører i Tidsskriftet nr. 21/2009 (1), nemlig at dårlige språkkunnskaper ikke er forenlig med forsvarlighetskravet i helsepersonelloven. Derfor forlangte fakultetet, i den perioden det var ansvarlig for gjennomføringen av medisinske fagprøve for utenlandske leger som søkte autorisasjon i Norge, at kandidatene på forhånd hadde dokumentert minimumskunnskaper i norsk. Kravet var enten bestått Bergens-test med en minimumsskår på 500 poeng eller norsk trinn III ved Universitetet i Oslo med god karakter. I tillegg måtte kandidatene gjennomgå et fire ukers norsk fagspråkkurs med avsluttende muntlig eksamen. I dag er situasjonen imidlertid den at leger fra EU/EØS-land, som Bulgaria, Romania, Ungarn, Polen, Slovenia og de baltiske statene, slipper å avlegge medisinsk fagprøve for å oppnå autorisasjon i Norge. Spørsmålet om hvorvidt deres norskkunnskaper er gode nok, overlates til deres fremtidige arbeidsgiver.

For såkalte tredjelandsleger (det vil si leger utdannet utenfor EU/EØS) som søker autorisasjon i Norge, er situasjonen en annen. Helsedirektoratet har de siste par årene bestilt en medisinsk fagprøve hos Det medisinske fakultet ved Universitetet i Oslo for å teste om disse kandidatene er faglig jevngode med våre egne kandidater som skal ut i turnus. Denne prøven arrangeres som en blanding av stasjoner der man tester praktiske og kliniske ferdigheter og gir et visst antall skriftlige oppgaver av typen flervalgsvar eller kortsvar. Helsedirektoratet og fakultetet har vært uenige når det gjelder kravet om forkunnskaper i norsk for disse kandidatene. Direktoratet hevdet at det var arbeidsgivers ansvar, mens Det medisinske fakultet forlangte at tredjelandslegene måtte dokumentere de samme minimumskunnskapene som nevnt over, bl.a. bestått fagspråkkurs, fordi det ville være meningsløst å arrangere en medisinsk fagprøve på norsk uten å stille forhåndskrav til språkkunnskap. Helsedirektoratet har akseptert dette, men kandidatene må selv betale utgiftene til det obligatoriske fagspråkkurset (per i dag kr 19000 per kandidat).

Mange av stasjonsoppgavene i den medisinske fagprøven tester nettopp norskkunnskaper i en klinisk situasjon. Sensorene på disse stasjonene er erfarne kolleger som, i tillegg til å vurdere de rent praktiske ferdighetene, også foretar en global vurdering av kandidatens egnethet. Etter å ha bestått prøven skal tredjelandslegene gjennomgå et kurs i såkalte nasjonale fag (organisering av norsk helsetjeneste, norsk trygdemedisin, rettspsykiatri o.1.). Kurset arrangeres av de fire medisinske fakultetene i fellesskap. Norsk språk og norsk medisinsk terminologi er et gjennomgående tema også i dette kurset. De fire fakultetene ønsker å strukturere dette kurstilbudet på en slik måte at arbeidsgiver vil se det som verdifullt og nødvendig for alle utenlandske leger, uansett om de kommer innenfra eller har sin bakgrunn utenfor EU/EØS.

I vår argumentasjon overfor helsemyndighetene har vi lagt vekt på viktigheten for pasientene av at legen forstår norsk og kan kommunisere med dem. Michael Bretthauer har i sin leder tydelig synliggjort de utenlandske legenes komplementære synspunkt: Å beherske språket er nødvendig for å gi legen den nødvendige trygghet overfor pasientene.

\section{Finn G.B. Wisløff}

Eric Rinvik

Universitetet i Oslo

\section{Litteratur \\ 1. Bretthauer M. Forstår du meg? Tidsskr Nor Lege- foren 2009; 129: 2211}

\section{Håndplukkede ledere betyr truet faglighet}

I Tidsskriftet nr. 24/2009 påpeker Petter Gjersvik med rette det paradoksale at klinikksjefene ved Oslo universitetssykehus utnevnes av direktøren, for deretter å bli universitetets representanter så sant de har akademisk kompetanse (1). Jeg har selv i flere år kjempet mot at sykehusdirektørene i praksis skal utnevne professorer og universitetsledere (2). Jeg har aldri forstått hvordan økonomer og administratorer kan ha grunnlag for å utnevne medisinske ledere eller universitetsledere. Dessverre har Det medisinske fakultet i Oslo og Universitetet i Oslo vært så svake at Rikshospitalets direktør og etter hvert direktøren for Oslo universitetssykehus egenhendig har ansatt de medisinske lederne. Det er bare noen få av oss som har protestert. Dette er imidlertid et spørsmål som burde engasjere mange - fordi det får store konsekvenser for norsk medisin og etter hvert også for pasientene. I dag vil ikke de best faglig kvalifiserte nå opp til toppstillingene ved Oslo universitetssykehus. Når vi ser på de nye ledernes akademiske profil, er det (bortsett fra et par hederlige unntak) svært tynt. Det er faktisk så tynt at ikke engang ledelsens pressemeldinger med orwellsk nytale om det motsatte virker beroligende.

Dagens ledere er håndplukket av direktøren. De vet at de har sine stillinger mer på grunn av direktørens velvilje enn på grunn av sine faglige kvalifikasjoner. Denne kvalitetsreduksjonen sprer seg raskt nedover i systemet - fordi sjefer har en tendens til å ansette folk med lavere kompetansenivå enn dem selv.

Etter hvert som professor 1-stillingene forsvinner, betyr dette også blant annet at den offentlige debatt med markerte medisinske profiler etter hvert vil forstumme $i$ vårt samfunn. Men - enda verre - motoren i norsk medisin for å få gjennom fremskritt er i ferd med å bli borte. Det er jo ikke slik at fremskritt kommer av seg selv. Det nye møter ofte motstand og krever mye innsats og arbeid fra fagets tradisjonsbærere, som ofte har vært professorene.

Vi er i ferd med å gå gjennom et ukontrollert medisinsk eksperiment uten sidestykke som ingen (så vidt jeg vet) har planer om å evaluere. Men erfaring fra Sverige og Finland viser at denne politikken svekker den medisinske forskningen. Dagens utvikling er mer enn bekymringsfull. Det er viktig at flere engasjerer seg i dette spørsmålet før norsk medisin har tapt for mange av sine kvaliteter!

Ola Didrik Saugstad

Oslo universitetssykehus, Rikshospitalet

Litteratur

1. Gjersvik P. Et fakultet styrt av klinikksjefer Tidsskr Nor Legeforen 2009: 129: 2628-9.

2. Saugstad OD. Gi sykehusene til de syke. Morgenbladet 25.9.2009. 